\title{
An Unusual Accident during a Molar Extraction: A Rare Case Report Breakage of Surgical Instrument an Uncommon Intra-Operative Complication
}

\author{
Ajit Joshi*, Manu Goel and Mayur J Gawande \\ Department of Oral \& Maxillofacial Surgery, Swargiya Dadasaheb Kalmegh Smruti Dental College \& Hospital, India
}

Submission: June 15, 2017; Published: November 17, 2017

*Corresponding author: Ajit Joshi, Reader, Department of Oral \& Maxillofacial Surgery, Swargiya Dadasaheb Kalmegh Smruti Dental College \& Hospital, Wanadongari Road, Hingana, Nagpur-440016, M.S, India, Tel: 09561121127; Email: dr.ajitjoshi@yahoo.in

\begin{abstract}
Background: Fracture of Surgical Instruments is an unusual intraoperative complication. Inappropriate handling of a surgical instrument or poor tools may lead to breakage of the instrument. This article presents a case of a dental elevator fracture during extraction of mandibular molar.

Case report: A 35 year-old male patient reported to the Department of Oral \& Maxillofacial Surgery at Swargiya Dadasaheb Kalmegh Smruti Dental College \& Hospital, Nagpur with chief complaint of pain in lower left back region of jaw since 1 month. But, it was observed that the dental elevator tip had broken during extraction by operator. The metallic fragment was removed to assure it completed the whole missing part of elevator.

Conclusion: All dental professionals should pay careful attention to the instruments used during dental procedures, especially the surgical ones. It is always advisable to afford reliable trademarks and products with quality control. Always, check the integrity of the instrument before and after the surgical procedure. If an incidence happens, dentists should take proper measures to solve the problem without further injury to the patient. If an unexpected incidence occurs, the patient must be informed and to manage the surgical complications.
\end{abstract}

Keywords: Instrument breakage; Elevator tip

\section{Introduction}

Accident can occurs from an operator technique intraoperatively due to number of factors including operator technique error and quality of surgical instruments. Manufacturer should follow the optimum standards, particularly in the case of dental, medical and surgical instruments which could cause serious injuries to patients. Despites adequate effort to perform tooth removal carefully, some mishaps may happen when substandard instruments are unknowingly used [1].

Dental elevator is an instrument used in minor oral surgical procedures to elevate the tooth or root from its socket. In literature, breakage of surgical instruments is an unusual intraoperative complication as compared to broken endodontic instruments.

Dental and Oral Surgeons should be particularly careful when metal instruments deployed with strong force are used in poorly visible area. If an unsuspected accident take place during surgical procedure the patient should be informed in accordance with ethical code, and suitable measures implemented to resolve the problem.
Aim of the present article is to report a case of fracture of a dental elevator tip during the extraction of mandibular molar.

\section{Case Description 1}

A 70 year-old male patient reported to the Department of Oral \& Maxillofacial Surgery at Swargiya Dadasaheb Kalmegh Smruti Dental College \& Hospital, Nagpur with chief complaint of missing teeth in lower left back region of jaw and wants to replace it. Clinical picture shows blackish discoloration in regions of lower left first molar region. After all required radiographic investigations, a well-defined radiopaque foreign body was detected in region of mandibular second molar region. Patient was operated under local anesthesia. Crestal incision was given in edentulous region of 46 and releasing incision was given on mucobuccal line angle of 47. Muco-periosteal flap was raised exposing the healed socket. The foreign body along with surrounding blackish discoloration was retrieved followed by curettage (Figure 1). The foreign body was found to be a tip of a Pencile. Smoothening of bony margin followed by thorough irrigation was carried out with betadine and normal saline. Flap 
was repositioned and sutured with 3-0 silk. Patient was kept for follow up and sutures were removed on 7 th day postoperatively. The healing was uneventful and painless.

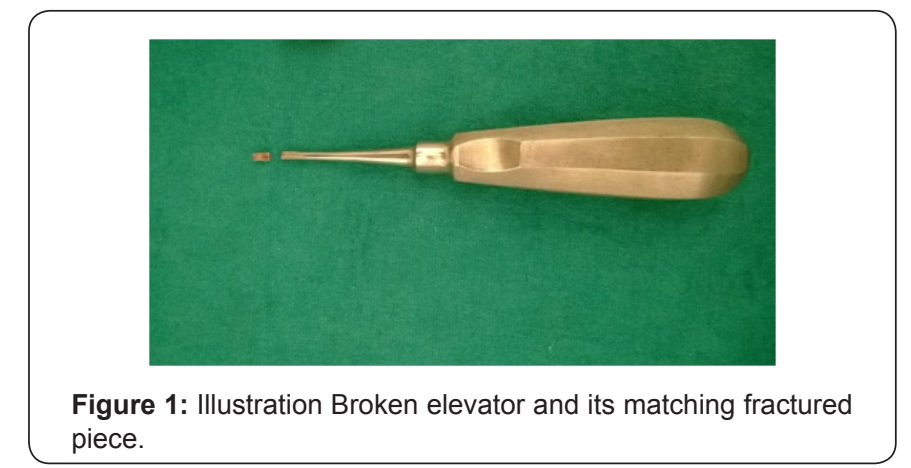

Case Description 2

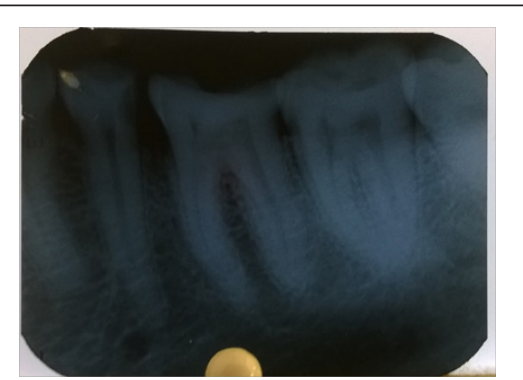

Figure 2: Illustration of IOPA with lower left first Molar.

A 35 year-old male patient reported to the Department of Oral \& Maxillofacial Surgery at Swargiya Dadasaheb Kalmegh Smruti Dental College \& Hospital, Nagpur with chief complaint of pain in lower left back region of jaw since 1 month. The tooth was firm with long roots (Figure 2). Extraction was carried out with the help of dental elevator (Coupland type). Surprisingly, the elevator's broken edge point was lodged in the mesial part of the first molar from where the elevator was applied. However, it was observed that the dental elevator tip had broken during extraction. The metallic fragment was removed to assure it completed the whole missing part of elevator (Figure $1 \& 3$ ). However, extraction was perform with routine dental forceps. Suture and postoperative medication were giving.

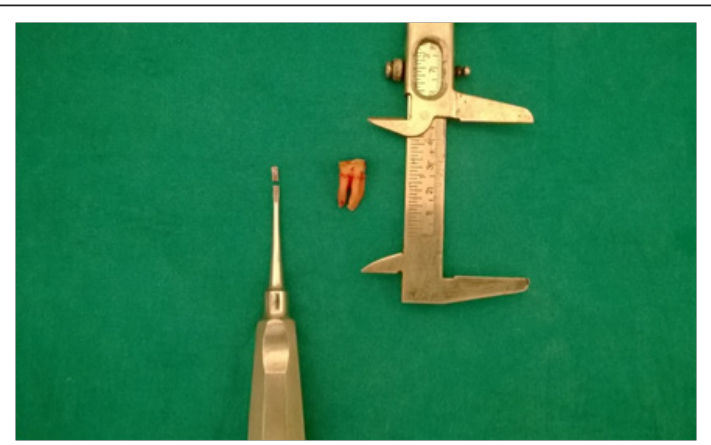

Figure 3: Illustration of extracted molar with broken elevator (Coupland) tip.

\section{Discussion}

In the literature, only three papers were found about broken surgical instruments during extraction procedures [2,3]. One of them reported three cases of broken new extraction elevators, which were found to be defective. The instruments were broken during routine use on three different patients on the same day and the fragments were found in the aspiration bottles, and were retrieved making unnecessary to radiate the patient to locate the fragment [2]. According to Whitehouse [4] reported two cases of broken dental forceps, where a broken fragment was rescued from the patient's mouth uneventfully, and in the other, the hinge pin came out of the forceps and was swallowed by the patient. The last paper reported the retrieval of an elevator's end that broke during the extraction of a lower right third molar, and was found with the aid of a metal detector (Keeler metal detector Goring Keeler Ltd., England)[3].

Moore [4] proved that the use of a metal detector was effective to pinpoint the metal presence in a surgical area. When placed near metal, the detector probe measures the change in the inductance, emitting different tones, thus locating the foreign body. The detector can also distinguish between different metals (steel, brass, aluminum, lead) emitting different signals, which can prove to be useful in a clinical situation.

In spite of all the difficulties that could arise during a broken fragment removal, it is always practical to try to remove the fragment in order to prevent it from migrating into a neighboring space. Even if metallic fragments could be enclosed in a fibrous tissue capsule when recognized by the organism as a foreign body, objects dislodged into the soft tissues on the lingual side of the mandible may gain access to the submandibular and parapharyngeal spaces [4].

According to Altan et al. [5] present three unusual cases of forgein body in the oral cavity In first case elevator was broken during impacted third molar surgery and it was missed out into the tissue. Second case Broken round bur piece was seen in the impacted third molar region. Third case broken drill bur was found in the mandibular fracture as a forgein body which were removed successfully [5].

On the other hand, a single intraoral periapical radiograph (IOPA) or tube-shift technique may be sufficient. In addition, occlusal radiography can also be employed as necessary. If an occlusal film is not available an intraoral periapical radiograph can be put on occlusally, or on the edentulous crest, and this may reveal an embedded foreign object. Cone beam computerized tomography (CBCT) is an excellent tool to locate metallic foreign objects. It can be used to locate the exact position of foreign body if inaccessible according to routine radiograph techniques [6].

Surgical instrument manufactures should carry out strict quality controls and have their instruments bear a visible mark as a sign of guarantee. Various authors have suggested that the 
inferior quality of some surgical instruments may be a reflection of poor working conditions and low standards tools, principally in the developing world. Responsibility lies with the suppliers from developed countries manufacturing in the developing world who behave in an unethical manner, maximizing profits and minimizing the compensation of the people who actually produce the goods $[7,8]$.
A safe and effective elevator should have extreme values for torque and stress values. Metal instruments used in clinical practise may be subjected to fatigue from sterilization. Standard Autoclave machine should be used for autoclaving and instruments should be kept dry to avoid corrosion, which ultimately weakens the instrument to avoid corrosion [9] (Table $1 \& 2)$.

Table 1:

\begin{tabular}{|r|}
\hline \multicolumn{1}{|c|}{ Prevention } \\
\hline Instruments should be kept dry to avoid corrosion which ultimately weakens the instrument. \\
\hline Standard Autoclave machine should be used for autoclaving. \\
\hline Strict autoclaving principles should be followed. \\
\hline Quality instruments approved by standardizing bureau of a particular nation should be used. \\
\hline Instruments should not be repaired or manipulated once any defect is detected. \\
\hline Substandard or Degraded instruments should not be used. \\
\hline Principles of Elevator must be followed strictly. \\
\hline Uncontrolled force should be avoided. \\
\hline
\end{tabular}

Table 2:

\begin{tabular}{|r|}
\hline \multicolumn{1}{|c|}{ Management } \\
\hline Radiological assessment should be practised using conventional or modern techniques available to ensure the foreign body. \\
\hline Instrument's working end should be examined after every procedure. \\
\hline If observed broken, it should be retrieved immediately followed by curettage. \\
\hline On diagnosis at later stage, a surgical removal should be performed under all aseptic precautions. \\
\hline
\end{tabular}

\section{Conclusion}

All Dental specialists should always pay careful attention to the instruments used during dental procedures, especially the surgical ones. It is always advisable to afford reliable trademarks and products with quality control. It is duty of dentist to check the surgical instrument for any sign of breakage before and after the surgical procedure. If an untoward accident happens, dentists should take the proper measures to solve the issue without further injury to the patient.

Accidents like the one described in this report have dentist's responsibility because accidents may result in litigation although it is impossible for dentists to prevent them from happening. In the present case report, although the accident may be attributed to a defective instrument, the patient has the right to prosecute the professional. Despite being a particular situation, it should be stressed out that accidents like the one here described should be dealt according to the different laws adopted by different countries.

\section{References}

1. Pierro VS, de Morais AP, Granado L, Maia LC (2010) An unusual accident during a primary molar extraction. J Clin Pediatr Dent 34(3): 193-195.
2. Ruprecht A, Ross A (1981) Location of broken instrument fragments. J Can Dent Assoc 47: 245.

3. Moore UJ, Fanibunda K, Gross MJ (1993) The use of a metal detector for localization of a metallic foreign body in the floor of the mouth. Br J Oral Maxillofac Surg 31(3): 191-192.

4. Whitehouse DJ (1995) Broken dental forceps. Br Dent J 178(10): 363.

5. Altan A, Damlar I, Kilic S, Turgay B (2013) Unusual forgein bodies in the oral cavity: a report of three cases. Sch J Dent Sci 2(2A): 126-129.

6. Eggers G, Welzel T, Mukhamadiev D, Wörtche R, Hassfeld S, et al. (2007) $\mathrm{X}$-ray-based volumetric imaging of foreign bodies: a comparison of computed tomography and digital volume tomography. J Oral Maxillofac Surg 65(9): 1880-1885.

7. Brophy T, Srodon PD, Briggs C, Barry P, Steatham J, et al. (2006) Quality of surgical instruments. Ann R Coll Surg Engl 88(4): 390-393.

8. Buttha MF (2007) Quality of surgical instruments. Ann R Coll Surg Engl 89(2): 190-192.

9. Kandler HJ (1982) The design and construction of dental elevators. J Dent 10(4): 317-322. 
This work is licensed under Creative Commons Attribution 4.0 Licens

DOI: 10.19080/JHNSS.2017.01.555570

\section{Your next submission with Juniper Publishers} will reach you the below assets

- Quality Editorial service

- Swift Peer Review

- Reprints availability

- E-prints Service

- Manuscript Podcast for convenient understanding

- Global attainment for your research

- Manuscript accessibility in different formats ( Pdf, E-pub, Full Text, Audio)

- Unceasing customer service

Track the below URL for one-step submission https://juniperpublishers.com/online-submission.php 